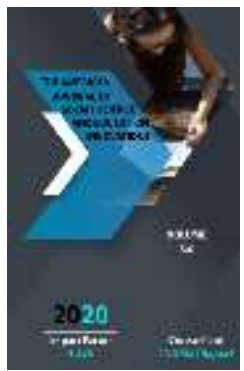

Journal Website: http://usajournalshub.c om/index,php/tajssei

Copyright: Original content from this work may be used under the terms of the creative commons attributes 4.0 licence.

\section{Use Of Management Methods In The Organization Of Pedagogical Processes}

\author{
Tohirova Farida Alimjanovna \\ Samarkand State Medical Institute, Uzbekistan \\ Uraqov Shokir Ulashovich \\ Samarkand State Medical Institute, Uzbekistan
}

Abdullayiva Sanobar Berdiyevna

Samarkand State Medical Institute, Uzbekistan

\title{
ABSTRACT
}

This article examines the use of various aspects of leadership in the organization and management of pedagogical processes, the timely and effective completion of tasks by students, the use of various aspects of leadership in the pedagogical process and the methods of leadership used by teachers in pedagogical processes.

\section{KEYWORDS}

Pedagogical processes, education, education, problems, methods, training, activities, knowledge, content and essence, ideas and concepts, scientific and methodological, measures.

\section{INTRODUCTION}

In the organization and management of pedagogical processes, it is possible to observe the use of various aspects of leadership methods in the formation of students' interest in learning, encouraging them to complete assignments in a timely and effective manner, ensuring their activity in pedagogical processes. Leadership methods used by teachers in pedagogical processes are determined on the basis of: 
- The level of independent and free thinking of students in the pedagogical process, the free expression of their thoughts, ideas and concepts, as well as their active participation in the situation;

- Providing students with scientific and methodological products, instructions on how to perform tasks, as well as the latest, scientifically based information and data;

- the formation of a favorable educational environment for all in the pedagogical process, the formation of subject relations;

- The methods of work used by professors and teachers in the educational process, ie their specific approach to relations with students.

Many experts focus on the priority of the relationship between individualism and collegiality as the main criterion and organizational principle of this process in the classification of leadership styles. Therefore, we will focus on the content and essence of leadership styles.

1. In the authoritarian (directive) style, professors try to impose their will on students through administrative force, that is, use coercion, intimidation, punishment and other measures. This method is based on direct commands and instructions and implies unconditional obedience of students, ie the freedom of students in pedagogical processes is limited and only professors and teachers act as the sole subject of the pedagogical process. Direct and free communication of students is limited. In this case, the attitude of students to the pedagogical process, their needs and interests are not taken into account psychologically.
It is a brutal style based on the principle of "separate and rule". This method, although somewhat effective, in fact, creates a mood of opposition, protest in the pedagogical process. Under the influence of this method, students are not satisfied with their learning activities, are not interested in its results, which in turn leads to a decrease in the effectiveness of the pedagogical process. There are different forms and methods of this style:

- Absolute-dictatorial form - professors and teachers act as the sole subject of the pedagogical process, in which students do not actively participate. Professors and teachers who use this method, without giving orders, coercion, intimidation, persuade students to do what they want.

seeks to subjugate, as a result of which students are motivated to study for education, that is, to study without satisfaction with their activities or interest in the subject, to study without personal interests and interests, to study for fear of failure, compulsory education;

- Autocratic method - means the concept of autocracy, that is, a bureaucratic form of government based on administrative command, assuming that the professors who exercise power have a wide range of opportunities and powers;

- In the patriarchal or matriarchal form, professors and teachers organize and manage the pedagogical process using the position of "head of the family", students have great confidence in them and are subordinated to them accordingly;

- Complimentary - charismatic form, in which professors pay attention to the unique qualities of personality, such as wisdom, kindness, heroism, courage 
uses a high-level position based on, students observe his behavior, the direction of his goals in the process of interaction, as well as respect his positive qualities, his inner worldview.

2. Liberal (free office) leadership style is characterized by the fact that professors give assignments and advice to students in the form of recommendations, less interference in the work of students. At the same time, professors and teachers act as mediators, giving students a wide range of independence, complete freedom in the pedagogical process, as well as their pays little attention to his movements and exercises control with sluggishness. He does not like to take responsibility, acts on the basis of agreement, that is, fulfills all their requirements so as not to disrupt the relationship with students. This, in turn, leads to the emergence of chaos in the pedagogical process, the behavior of students and the direction of educational activities.

- Leads to a weakening of control, the loss of their interest in a particular subject, as well as a decrease in the activity of students in other pedagogical processes.

Based on the above, the following methods and forms of this leadership style can be distinguished:

- Communicative tendency - in which professors and teachers give students the opportunity to ask a variety of questions, to express their opinions, this is an advisory method of management, the proposals given by students, their opinions, the results of the tasks performed by them. done on time;

- Management-pedagogical on the basis of joint decisions
Problem-solving techniques are widely used in the process, and professors and teachers involve all students to find a solution to the problem, and determine the order of solving the problem, as well as the decision-making process by students, while retaining all their rights and powers.

3. In a democratic (collegial) method, proofreaders do not act as a single subject of the pedagogical process, they base their activities on students and their opinions, that is, in the pedagogical process, students think independently and freely, freely demonstrate their abilities. to create the necessary conditions for the free expression of their views through which they focus on ensuring their activism. In the pedagogical process on the basis of the formation of subject-subject relations (professor-teacher and student-student) a favorable educational environment is created for all.

The rational use of leadership methods in the pedagogical process, depending on the situation, creates a mutual trust, mutual understanding, friendship and a favorable educational environment for all professors and students. The professor-teacher behaves as a participant in the pedagogical process, in front of which each student feels free and thinks independently and freely, and the resulting initiatives, ideas and thoughts easily represents. Professors and teachers who use this method encourage initiative in the pedagogical process, treat all students equally and sincerely, do not express the superiority of their position, create a favorable environment for cooperation, allow students to participate freely, they responds appropriately to the criticism expressed by and takes appropriate 
approaches to it, taking into account different situations.

Based on the use of such a method of leadership in the organization and management of pedagogical processes, the following methods and forms can be distinguished in the direction of ensuring the activity of the subjects:

- Innovation management, which involves the development and implementation of innovations that serve the development of an educational environment that is conducive to all, based on the encouragement of initiative and innovation of subjects in pedagogical processes;

- Goal-oriented task management - is to ensure the active participation of students through the distribution of tasks, study, analysis, objective assessment and motivation, taking into account the level of capabilities and basic concepts, developing students' interest in possible and achieved achievements :

- planning of management-innovation processes through the interaction of subjects, as well as ensuring the participation of students in the process of its implementation and maintenance;

- goal-directed management - this method is goal-oriented is an interconnected form of management through the interaction of tasks and subjects, in which students participate in the pre-determination of the results to be achieved and the directions for achieving the desired results are agreed;

- Management by results - the priority is to identify specific ways to achieve results. This project requires assignment of tasks, control system, incentives and assignments based on a clear plan;

- Management through the distribution of tasks - the ability to work independently, the distribution of tasks among students who have a basic understanding of the assigned task, a sense of responsibility;

- Management through motivation - the individuality of students provides management by organizing incentives that meet their needs;

- Management through the development of the process - the functional responsibilities of teachers in the pedagogical process are clearly distinguished by direct influence and control;

- Management through personal development - in this method, special attention is paid to the development of the student's personality, that is, their independent work, independent engagement serves to ensure the effectiveness of pedagogical processes.

Leadership methods are the most necessary and basic organizational element in the organization and management of pedagogical processes and depend on the individual characteristics of the personality of professors and teachers. None of these methods can be claimed to be universal in the pedagogical process and in all situations that arise in its organization and management.

Therefore, one of the most important qualities of teachers in the organization and management of pedagogical processes is the ability to use different methods, that is, the ability to use leadership methods wisely in different situations.

In the organization and management of pedagogical processes, professors and 
teachers should take into account the following factors when choosing this or that method of leadership:

- Situation (stress, calm undetected). For example, authoritarian style justifies itself in time-constrained situations;

- Assignment (depending on complexity). When assigning complex tasks to students, it is necessary to take into account their capabilities, abilities and initial concepts, to organize roundtables on the content, importance and direction of the tasks, and to create opportunities for students to choose tasks of particular importance.

- Group (sex, age, abilities and capabilities of its members).

It is advisable to choose a democratic or liberal style for groups that are interested in the performance of tasks, have a mutual understanding (opportunities to apply a creative approach to the performance of tasks, are inquisitive).

The use of leadership techniques in the organization and management of pedagogical processes will have variable characteristics depending on the situation, covering a multilevel framework. These features include the ability to change leadership styles in response to rapidly changing situations in the pedagogical process, pedagogical process is characterized by the activity of the subjects, the level of knowledge, skills and abilities and the development of their needs, the combination of personal interests with common interests, and other reasons.

\section{REFERENCES}

1. Abdurahmonov Q., Yu.Odegov va boshqalar. Personalni boshqarish. Toshkent: "Sharq", 1998.

2. Abdurahmonov Q.H., D.N.Rahimova va boshqalar. Davlat xizmati personalini boshqarish. - Toshkent: "Akademiya”, 2002.

3. Adizova T. M. Boshqaruv muloqoti. Toshkent: Nizomiy nomli TDPU, 2000.

4. Ahlidinov R. Sh. O'zbekiston Respublikasida ta'lim muassasasi ta'limi tizimini boshqarish xususiyatlari(nazariy-metodologik jihatlar). - Toshkent: O‘zPFITI, 1997.

5. Turg'unov S. T. "Pedagogika" fanidan ma'ruzalar to'plami. -Namangan: NamMPI, 1999.

6. Turg'unov S. T. Zamonaviy ta'lim muassasasi rahbarlarining funksional vazifalari. - Namangan: NVPQTMOI, 2004. 